\title{
APLIKASI LIMBAH CAIR NANAS DAN KOMPOS KOTORAN SAPI UNTUK MENINGKATKAN POPULASI MIKROORGANISME PELARUT FOSFAT DI ULTISOL, LAMPUNG TENGAH
}

\section{APPLICATIONS OF PINEAPPLE LIQUID WASTE AND COW DUNG COMPOS TO IMPROVE POPULATION OF PHOSPHATE SOLUBILIZING MICROORGANISM IN ULTISOL, CENTRAL LAMPUNG}

\author{
Winih Sekaringtyas Ramadhani ${ }^{1 凶}{ }^{\text {, Eko Handayanto }}{ }^{2}$, Yulia Nuraini ${ }^{2}$, Ali Rahmat ${ }^{1}$ \\ ${ }^{1}$ Jurusan Ilmu Tanah, Fakultas Pertanian, Universitas Lampung \\ ${ }^{2}$ Jurusan Ilmu Tanah, Fakultas Pertanian, Universitas Brawijaya

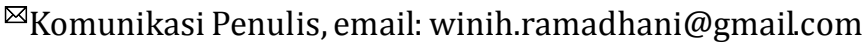 \\ DOI:http://dx.doi.org/10.23960/jtep-lv9i2.78-84
}

Naskah ini diterima pada 13 Februari 2020; revisi pada 27 April 2020;

disetujui untuk dipublikasikan pada 27 Mei 2020

\begin{abstract}
Decreased production of pineapple in Lampung allegedly because of decreased soil fertility. This is due to intensive landuse and the type of soil cultivated is Ultisol Ultisol has characteristics, acidic $p H$, low availability of nutrients, high alumunium saturation and low microba activity in the soil. The purpose of this research was to determine population of phosphate solubilizing microorganism after application of cow dung compost and pineapple liquid waste in the Ultisol, Central Lampung. This research was conducted by incubation in a greenhouse with observation intervals of 0, 30 and 60 days. Observation of microbial population of phosphate solubilizing using pikoskaya. The experiment used a completely randomized design and Data obtained from the experiments was analyzed using the analysis of variance at 95\% significant level, followed by Duncan test at $5 \%$ level. The results showed that the application of $20.000 \mathrm{~L} \mathrm{ha}^{-1}$ of pineapple liquid waste and application $20 \mathrm{tha} \mathrm{g}^{-1}$ of cow dung compost (K3L3) in the Ultisol, significantly increase microbial population of phosphate solubilizing $\left(36,67 \times 10^{2} \mathrm{cfu} \mathrm{g}^{-1}\right)$ if comparedto the application of $20 \mathrm{tha}^{-1} \mathrm{cow}$ dung compost (K3LO) in Ultisol $\left(22,33 \times 10^{2} \mathrm{cfu} \mathrm{g^{-1 }}\right)$ at 30 days of observation. However application of cow dung compost has a higher microbial population of phosphate solubilizing if compared to application of pineapple liquid waste alone.
\end{abstract}

Keywords : cow dung compost, pineapple liquid waste, population microbia of phosphate solubilizing

\begin{abstract}
ABSTRAK
Penurunan produksi Nanas di Lampung diduga karena adanya penurunan kesuburan tanah. Hal ini dikarenakan penggunaan lahan secara intensif serta jenis tanah budidaya adalah Ultisol. Tanah Ultisol memiliki karakteristik $\mathrm{pH}$ tanah yang masam, rendahnya ketersediaan hara, tingginya kejenuhan almunium serta rendahnya aktivitas mikroba dalam tanah. Penelitian ini bertujuan untuk mengetahui jumlah populasi mikroba pelarut fosfat setelah diaplikasikan kompos kotoran sapi dan limbah cair nanas di tanah Ultisol, Lampung Tengah. Penelitian ini dilakukan dengan cara inkubasi di rumah kaca dengan interval pengamatan 0, 30 dan 60 hari. Pengamatan total mikroba pelarut fosfat menggunakan media pikovskaya. Percobaan menggunakan Rancangan Acak Lengkap (RAL) dan dilakukan analisis ragam dengan tingkat signifikan 95\%, kemudian dilakukan uji Duncan 5\%. Hasil penelitian menunjukkan bahwa penambahan $20.000 \mathrm{~L} \mathrm{ha}^{-1}$ limbah cair nanas dan $20 \mathrm{t} \mathrm{ha}^{-1} \mathrm{kompos}$ (K3L3) di tanah Ultisol, secara nyata meningkatkan jumlah mikroorganisme pelarut fosfat $\left(36,67 \times 10^{2} \mathrm{cfu} \mathrm{g}^{-1}\right)$ dibandingkan penambahan kompos kotoran sapi $20 \mathrm{t} \mathrm{ha}^{-1}$ (K3L0) saja di tanah Ultisol $\left(22,33 \times 10^{2} \mathrm{cfu} \mathrm{g}^{-1}\right)$ pada 30 hari pengamatan. Namun penambahan kompos kotoran sapi memiliki total populasi mikroorganisme pelarut fosfat lebih tinggi dibandingkan dengan hanya aplikasi limbah cair nanas saja.
\end{abstract}

Kata Kunci: kompos kotoran sapi, limbah cair nanas, populasi mikroba pelarut fosfat 


\section{PENDAHULUAN}

PT. Great Giant Pineapple (PT. GGP) merupakan perusahaan eksportir nanas terbesar yang berada di Provinsi Lampung. Namun hasil produksi nanas di Lampung mengalami penurunan dari tahun 2014 (560,04 ton) dan tahun 2015 (534,77 ton) (Ramadhani and Nuraini, 2018). Penurunan produksi nanas diduga disebabkan oleh rendahnya kesuburan tanah. Ramadhani dan Nuraini (2018) menjelaskan bahwa penurunan kesuburan tanah dikarenakan penggunaan lahan yang intensif dalam penggunaan pupuk kimia dan penanaman tanaman nanas secara monokultur.

Dey et al. (2012) menjelaskan bahwa tanaman nanas yang ditanam secara monokultur memiliki kandungan C-organik 2,3\% dan tanaman nanas yang ditanam dengan system tanam polikultur memiliki C-organik 4,03\%. Selain itu penurunan kesuburan tanah diduga karena jenis tanah di Provinsi Lampung umumnya berjenis Ultisols. Prasetyo dan Suriadikarta (2006) menyatakan bahwa tanah Ultisol memiliki pH masam $(3,1$ 5), miskin hara fosfor, kejenuhan almunium yang tinggi ( $>60 \%)$ serta memiliki kandungan bahan organik dan aktivitas biologi yang rendah (Tando et. al., 2017). Chaudhuri et al. (2016) memaparkan bahwa tingginya produksi buah nanas berkaitan dengan ketersediaan hara di dalam tanah. Upaya yang telah dilakukan untuk meningkatkan kesuburan tanah di PT. GGP dengan menambahkan kompos kotoran sapi ke lahan budidaya.

Sanni (2016) memaparkan bahwa kotoran hewan efektif dalam meningkatkan kesuburan tanah dan pertumbuhan tanaman. Obiamaka (2011) menjelaskan bahwa pemberian kotoran sapi secara signifikan meningkatkan $\mathrm{pH}, \mathrm{Ca}, \mathrm{Mg}$, P-tersedia dalam tanah. Akinde dan Obire (2008), melaporkan bahwa total bakteri yang terdapat pada kotoran sapi sebesar $74,25 \times 10^{5} \mathrm{cfu} \mathrm{g}^{-1}$. Jenis bakteri pada kotoran sapi yaitu Acinetobacter sp, Bacillus sp, Pseudomonas sp dan Serratia sp. Kotoran sapi berkontribusi dalam meningkatkan keberagaman mikroorganisme serta meningkatkan ketersediaan nitrogen dan fosfor. Purwaningsih (2003) menyatakan bahwa Pseudomonas sp merupakan salah satu bakteri pelarut fosfat yang dapat melarutkan fosfor lebih tinggi sebesar $5,74 \times 10^{6} \mathrm{cfu} \mathrm{m}^{-1}$ dibandingkan dengan jamur sebesar 5,1 x $10^{6} \mathrm{cfu} \mathrm{ml}^{-1}$ (Tamad dan Maryanto, 2010). Bhattacharya et al. (2013) mengungkapkan bahwa aplikasi mikroorganisme pelarut fosfat ke dalam tanah sebagai pupuk hayati dapat melarutkan unsur hara yang tidak tersedia menjadi tersedia. Namun ketersediaan kompos kotoran sapi yang rendah mengakibatkan tidak dapat memenuhi pasokan seluruh lahan. Oleh karena itu perlu dilakukan penambahan bahan yang berlimpah untuk meningkatkan hara di PT. GGP. Salah satu bahan yang berlimpah di PT. GGP yaitu limbah cair nanas.

Limbah cair nanas yang berlimpah di PT. GGP merupakan sumber masukan ke dalam tanah yang sangat potensial. Abdulah dan Mat (2008) melaporkan bahwa limbah cair nanas mengandung $\mathrm{K}\left(526 \mathrm{mg} \mathrm{L}^{-1}\right)$, Ca (194 $\left.\mathrm{mg} \mathrm{L}^{-1}\right)$ dan P (27,4 $\left.\mathrm{mg} \mathrm{L}^{-1}\right)$. Zakaria et al. (2007) menjelaskan bahwa limbah cair nanas digunakan sebagai sumber energi bakteri karena mengandung glukosa, fruktosa dan sukrosa untuk menghasilkan asam sitrat (Dacera dan Babel, 2007). Asam stitrat digunakan mikroorganisme sebagai sarana utama dalam melarutkan P (Khan et al., 2014). Kumar et al. (2003) menjelaskan bahwa limbah cair nanas digunakan oleh Aspergilus niger sebagai substratnya dalam memproduksi asam sitrat sebesar 11,3 g $100 \mathrm{~g}^{-1}$ dengan kelembapan 70\% setelah 8 hari. Dacera dan Babel (2007) menambahkan, bahwa asam sitrat yang diperoleh dari limbah nanas yang difermentasi oleh Aspergilus niger dapat menghilangkan logam berat. Oleh karena itu perlu dilakukan penelitian dampak penambahan limbah cair nanas dan kompos kotoran sapi terhadap jumlah mikroba (jamur dan bakteri) pelarut fosfat di tanah Ultisol.

\section{BAHAN DAN METODA}

Penelitian ini dilakukan di PT. Great Giant Pineapple, Terbanggi Besar, Lampung Tengah pada bulan November 2017 hingga Mei 2018. Bahan yang digunakan dalam penelitian ini antara lain: limbah cair nanas, kompos kotoran sapi dan tanah Ultisol. Karakteristik tanah yang digunakan penelitian yaitu: $\mathrm{pH}\left(\mathrm{H}_{2} \mathrm{O}\right) 4,17$; C- 
organik 1,76\% N-total 0,17\% dan P-tersedia 0,95 me/100g. Limbah cair nanas yang digunakan dalam penelitian memiliki karakteristik antara lain $\mathrm{pH} 3.04$, total nitrogen $0,08 \%$, C-organik $0,02 \%$, total fosfor $0,37 \%$, glukosa $43 \mathrm{mg} \mathrm{L}^{-1}$, sukrosa $29,5 \mathrm{mg} \mathrm{L}^{-1}$, fruktosa $26 \mathrm{mg} \mathrm{L}^{-1}$ dan total mikroba pelarut fosfat $45 \times 10^{2} \mathrm{cfu} \mathrm{ml}^{-1}$. Kompos kotoran sapi yang digunakan dalam penelitian memiliki karakteristik C-organik 16,58\%, pH 6.67, P-total 0,02\% dan N-total 0,32\%. Penelitian ini dilakukan dengan percobaan inkubasi di rumah kaca.

Rancangan penelitian dilakukan dengan Rancangan Acak Lengkap (RAL) dengan dosis kompos dan limbah cair nanas pada Tabel 1. Masing-masing perlakuan dilakukan pengulangan sebanyak 3 kali ulangan, sehingga terdapat 48 unit percobaan (sketsa pecobaan dapat dilihat di gambar 1). Masing-masing perlakuan (Tabel 1) dicampurkan dengan $10 \mathrm{~kg}$ tanah (lolos ayakan $2 \mathrm{~mm}$ dan kering udara) selanjutnya dimasukkan dalam polybag. Penyiraman dilakukan berdasarkan keadaan kapasitas lapang 50\%. Pengamatan populasi mikroba pelarut fosfat menggunakan media Pikovskaya dengan interval pengamatan 0,30 dan 60 hari. Data yang dihasilkan selanjutnya dianalisis ragam dengan taraf $95 \%$ diikuti dengan uji Duncan taraf 5\%.

Tabel 1. Satuan Percobaan Penelitian Aplikasi Limbah Cair Nanas Dengan Kompos Kotoran Sapi di Ultisol

\begin{tabular}{|c|c|c|}
\hline No & Kode & Perlakuan \\
\hline 1 & KOLO & Kontrol \\
\hline 2 & K1L0 & 10 t Kompos kotoran sapi ha-1 \\
\hline 3 & $\mathrm{~K} 2 \mathrm{LO}$ & 15 t Kompos kotoran sapi ha-1 \\
\hline 4 & $\mathrm{~K} 3 \mathrm{LO}$ & 20 t Kompos kotoran sapi ha-1 \\
\hline 5 & KOL1 & 10000 L Limbah Cair Nanas ha-1 \\
\hline 6 & KOL2 & 15000 L Limbah Cair Nanas ha-1 \\
\hline 7 & K0L3 & 20000 L Limbah Cair Nanas ha ${ }^{-1}$ \\
\hline 8 & K1L1 & 10 t Kompos kotoran sapi ha $^{-1}+10000$ L Limbah Cair Nanas ha $^{-1}$ \\
\hline 9 & K1L2 & 10 t Kompos kotoran sapi ha ${ }^{-1}+15000$ L Limbah Cair Nanas ha $^{-1}$ \\
\hline 10 & K1L3 & 10 t Kompos kotoran sapi ha ${ }^{-1}+20000$ L Limbah Cair Nanas ha-1 $^{-1}$ \\
\hline 11 & K2L1 & 15 t Kompos kotoran sapi ha ${ }^{-1}+10000$ L Limbah Cair Nanas ha $^{-1}$ \\
\hline 12 & $\mathrm{~K} 2 \mathrm{~L} 2$ & 15 t Kompos kotoran sapi ha ${ }^{-1}+15000$ L Limbah Cair Nanas ha $^{-1}$ \\
\hline 13 & $\mathrm{~K} 2 \mathrm{~L} 3$ & 15 t Kompos kotoran sapi ha ${ }^{-1}+20000$ L Limbah Cair Nanas ha $^{-1}$ \\
\hline 14 & K3L1 & 20 t Kompos kotoran sapi ha $^{-1}+10000$ L Limbah Cair Nanas ha $^{-1}$ \\
\hline 15 & $\mathrm{~K} 3 \mathrm{~L} 2$ & 20 t Kompos kotoran sapi ha ${ }^{-1}+15000$ L Limbah Cair Nanas ha $^{-1}$ \\
\hline 16 & K3L3 & 20 t Kompos kotoran sapi ha ${ }^{-1}+20000$ L Limbah Cair Nanas ha $^{-1}$ \\
\hline
\end{tabular}

\begin{tabular}{|l|l|l|l|l|l|l|l|l|l|l|}
\hline K1L0 U1 & K2L0 U3 & K3L0 U1 & K2L1 U1 & K3L2 U1 & K1L1 U3 & K3L3 U1 & K0L0 U2 \\
\hline K1L1 U2 & K2L2 U2 & K3L1 U3 & K0L3 U3 & K0L0 U1 & K3L0 U3 & K1L3 U3 & K1L0 U3 \\
\hline K0L0 U3 & K3L1 U1 & K1L2 U1 & K1L0 U2 & K2L3 U3 & K0L2 U1 & KOL2 U2 & K2L1 U2 \\
\hline K2L3 U1 & K0L2 U3 & K1L2 U2 & K0L1 U1 & KOL3 U2 & K1L2 U3 & K0L1 U2 & K3L1 U2 \\
\hline K2L0 U2 & K1L3 U1 & K1L1 U1 & K2L3 U2 & K0L1 U3 & K3L3 U2 & K2L2 U1 & K3L3 U3 \\
\hline K3L2 U3 & K2L0 U1 & K1L3 U2 & K2L2 U3 & K2L1 U3 & K0L3 U1 & K3L2 U2 & K3L0 U2 \\
\hline
\end{tabular}

Gambar 1. Gambar Sketsa Tata Letak Percobaan 


\section{HASIL DAN PEMBAHASAN}

Penambahan kompos kotoran sapi dan limbah cair nanas secara nyata dapat meningkatkan jumlah mikroba pelarut fosfat dibandingkan dengan kontrol pada 30 dan 60 hari setelah inkubasi, hal ini terlihat pada Tabel 2. Jumlah populasi mikroba pelarut fosfat tertinggi pada perlakuan K3L3 pada pengamatan 30 dan 60 hari. Selain itu pada pengamatan 30 hari, menunjukkan kombinasi limbah cair nanas dan kompos kotoran sapi mengalami peningkatan total populasi mikroba lebih tinggi dibandingkan hanya aplikasi limbah cair nanas saja ataupun kompos kotoran sapi saja. Perlakuan dengan penambahan kompos kotoran sapi saja mengalami peningkatan populasi mikroba pelarut fosfat secara signifikan dibandingkan dengan perlakuan hanya penambahan limbah cair nanas. Perlakuan K3L3 memiliki penambahan mikroba pelarut fosfat lebih tinggi dibandingkan dengan perlakuan lainnya (Tabel 2). Hal ini selaras dengan parameter populasi mikroba pelarut fosfat pada kompos kotoran sapi $\left(61,7 \times 10^{2} \mathrm{cfu}^{-1}\right)$ lebih tinggi dibandingkan dengan populasi mikroba pelarut fosfat pada limbah cair nanas ( $\left.45 \times 10^{2} \mathrm{cfu} \mathrm{g}^{-1}\right)$. Namun perlakuan dengan kombinasi limbah cair nanas dan kompos kotoran sapi mampu meningkatkan populasi mikroba pelarut fosfat.

Limbah cair nanas dapat digunakan sebagai substrat bagi mikroorganisme. Zakaria et al. (2007) menjelaskan, bahwa limbah cair nanas dapat digunakan sebagai sumber energi mikroorganisme, karena mengandung glukosa, fruktosa dan sukrosa yang mampu menghasilkan asam sitrat (Dacera dan Babel, 2007). Mikroba menghasilkan asam sitrat yang memiliki gugus karboksi $\mathrm{COOH}^{-}$(Dacera et al., 2009). Ginting et al. (2006) menjelaskan aktivitas mikroba pelarut fosfat dipengaruhi oleh pH tanah, karena mempengaruhi metabolisme mikroorganisme. Selain itu, penambahan bahan organik mampu menyeimbangkan nutrisi dan mengurangi keasaman tanah (Ogbomo dan Osaigbovo (2017). Penambahan limbah cair nanas $20.000 \mathrm{~L} \mathrm{ha}^{-1}$ dan 20 tha $^{-1}$ kompos kotoran sapi memiliki pH tanah 5,12 dibandingkan hanya dengan pemberian kompos kotoran sapi 20 tha ${ }^{1}(4,82)$ dan hanya pemberian limbah cair nanas $20.000 \mathrm{~L} \mathrm{ha}^{-1}(4,16)$ (Ramadhani dan Nuraini, 2018). Abegunrin et al. (2016) menyatakan aplikasi kompos kotoran sapi $20 \mathrm{t} \mathrm{ha}^{-1}$ dapat meningkatan $\mathrm{pH}$ tanah sebesar 6,75 dibandingkan dengan tanpa pemberian kompos kotoran sapi $(6,05)$.

Tabel 2. Pengaruh Inkubasi Kompos Kotoran Sapi dan Limbah Cair Nanas terhadap Total Mikroorganisme Pelarut Fosfat di Ultisol

\begin{tabular}{cccc}
\hline \multirow{2}{*}{ Perlakuan } & \multicolumn{3}{c}{ Jumlah Mikroba Pelarut Fosfat (cfu g-1) pada hari ke } \\
\cline { 2 - 4 } & $\mathbf{0}$ & $\mathbf{3 0}$ & $\mathbf{6 0}$ \\
\hline K0L0 & $3,30 \times 10$ & $6,670 \times 10 \mathrm{a}$ & $13,3 \times 10 \mathrm{ab}$ \\
K0L1 & $13,3 \times 10$ & $46,70 \times 10 \mathrm{c}$ & $23,3 \times 10 \mathrm{~b}$ \\
K0L2 & $8,30 \times 10$ & $33,30 \times 10 \mathrm{~b}$ & $6,67 \times 10 \mathrm{a}$ \\
K0L3 & $20,0 \times 10$ & $116,7 \times 10 \mathrm{e}$ & $80,0 \times 10 \mathrm{~d}$ \\
K1L0 & $13,3 \times 10$ & $73,30 \times 10 \mathrm{~d}$ & $46,7 \times 10 \mathrm{c}$ \\
K1L1 & $5,00 \times 10$ & $110,0 \times 10 \mathrm{e}$ & $80,0 \times 10 \mathrm{~d}$ \\
K1L2 & $16,7 \times 10$ & $130,0 \times 10 \mathrm{f}$ & $6,70 \times 10 \mathrm{a}$ \\
K1L3 & $3,30 \times 10$ & $250,0 \times 10 \mathrm{~h}$ & $120,0 \times 10 \mathrm{f}$ \\
K2L0 & $6,70 \times 10$ & $116,7 \times 10 \mathrm{e}$ & $106,7 \times 10 \mathrm{e}$ \\
K2L1 & $13,1 \times 10$ & $243,3 \times 10 \mathrm{~h}$ & $113,3 \times 10 \mathrm{ef}$ \\
K2L2 & $11,7 \times 10$ & $250,0 \times 10 \mathrm{~h}$ & $140,0 \times 10 \mathrm{~g}$ \\
K2L3 & $18,3 \times 10$ & $280,0 \times 10 \mathrm{i}$ & $200,0 \times 10 \mathrm{i}$ \\
K3L0 & $15,0 \times 10$ & $223,3 \times 10 \mathrm{~g}$ & $180,0 \times 10 \mathrm{~h}$ \\
K3L1 & $21,7 \times 10$ & $276,7 \times 10 \mathrm{i}$ & $206,7 \times 10 \mathrm{i}$ \\
K3L2 & $18,0 \times 10$ & $330,0 \times 10 \mathrm{j}$ & $250,0 \times 10 \mathrm{j}$ \\
K3L3 & $18,3 \times 10$ & $366,7 \times 10 \mathrm{k}$ & $320,0 \times 10 \mathrm{k}$ \\
\hline
\end{tabular}


Ramadhani dan Nuraini (2018) menjelaskan bahwa peningkatan mikroba pelarut fosfat diikuti dengan peningkatan P-tersedia dalam tanah setelah penambahan limbah cair nanas dan kompos kotoran sapi. Perlakuan penambahan limbah cair nanas $20000 \mathrm{~L} \mathrm{ha}^{-1}$ dan $20 \mathrm{t} \mathrm{ha}^{-1}$ kompos kotoran sapi memiliki P-tersedia lebih tinggi $(91,87$ ppm) dibandingkan dengan perlakuan dengan penambahan 20 tha $^{-1}(84,10$ ppm) pada pengamatan 30 hari. Peningkatan Ptersedia ini berkaitan dengan peningkatan $\mathrm{pH}$ tanah dan penurunan kejenuhan almunium dalam tanah. pH pada perlakuan K3L3 $(5,12)$ memiliki $\mathrm{pH}$ lebih tinggi dibandingkan dengan K3L0 $(4,82)$ pada 30 hari pengamatan. Kejenuhan aluminium pada perlakuan limbah cair nanas K3L3 kompos kotoran sapi lebih rendah $(0,13 \mathrm{me} / 100 \mathrm{~g})$ dibandingkan dengan perlakuan K3L0 $(0,17 \mathrm{me} / 100 \mathrm{~g})$ pada 30 hari pengamatan. Rahayu et al. (2012) menjelaskan, Aluminium (Al) sangat berpengaruh terhadap $\mathrm{pH}$ tanah. Kelarutan Al yang tinggi akan meningkatkan kemasaman tanah sehingga menyebabkan kelarutan unsur hara $P$ tidak tersedia. Hal ini karena $\mathrm{P}$ terikat oleh $\mathrm{Al}$. Penambahan bahan organik mampu melepaskan $P$ yang terjerap hal ini karena terdapat asam organik (asam sitrat, asam malat dan asam asetat) merupakan anion pesaing yang dapat menutup permukaan mineral allofan dan oksida hidrat Al sehingga mendorong pelepasan Panorganik. Bhattacharya et al. (2013) mengungkapkan bahwa pengaplikasian mikroorganisme pelarut fosfat ke dalam tanah sebagai pupuk hayati dapat melarutkan unsur hara tidak tersedia menjadi unsur hara tersedia. Limbah cair nanas memiliki asam organik khususnya asam sitrat yang memiliki gugus karboksi $\mathrm{COOH}^{-}$yang dapat digunakan sebagai pengkelat dan penyerap ion logam (Dacera et al., 2009). Elfiati et al. (2016) menjelaskan bahwa asam organik memiliki gugus karboksil $\mathrm{COOH}^{-}$bereaksi dengan pengikat fosfat yaitu $\mathrm{Al}^{3+}$ dan $\mathrm{Fe}^{2+}$ membentuk ikatan sehingga dapat melarutkan fosfat dan kandungan Al dan Fe akan mengendap.

\section{KESIMPULAN DAN SARAN}

Penambahan limbah cair nanas dan kompos kotoran sapi mampu meningkatkan populasi mikroba pelarut fosfat di tanah Ultisol, Lampung Tengah. Perlakuan pemberian 20 tha $^{-1}$ kompos kotoran sapi dan $20000 \mathrm{~L} \mathrm{ha}^{-1}$ limbah cair nanas memiliki total populasi mikroba pelarut fosfat lebih tinggi dibandingkan dengan perlakuan lainnya.

\section{DAFTAR PUSTAKA}

Abdulah dan Mat, H. 2008. Characterisation of Solid and Liquid Pineapple waste. Reaktor, 12 (1): 48-52

Abegunrin, T.P, Awe, G.O. dan Ateniola, K.O. 2016. Soil Amendment for Vegetable Production: An Expemle With Cow Dug and Eggplant (Solanum melongena). International Journal of Current Microbiologi and Applied Sciences 5 (8): 901-915.

Akinde, S.B. dan Obire, 0. 2008. Aerobic Heterotrophic Bacteria and PetroleumUtilizing Bacteria from Cow Dung and Poultry Manure. World Journal Microbiology Biotechnology 24 :19992002.

Bhattacharya, S.S., Barman. S., Ghosh, R. dan Duary, R.K. 2013. Phosphate Solubilizing Ability of Emericella nidulans Strain V1 Isolated From Vermicompost. Indian Journal of Experimental Biology 15: 840848.

Chaudhuri, P.S., Paul, T. K., Dey, A., Datta, M. dan Dey, S.K. 2016. Effects of Rubber Leaf Litter Vermicompost on Eartworm Population and Yield of Pineapple (Ananas comosus) in West Tripura, India. International Journal Recycel Organitation Waste Agriculture CrossMark Original Research 5: 93-103.

Dacera, D.D.M. dan Babel, S. 2007. Heavy Metals Removal From Contaminated Sewage Sludge by Naturally Fermented Raw Liquid From Pineapple Wates. Water Science and Techology 56(7): 145-152.

Dacera, D.D.M., Babel, S., dan Parkpian, P. 2009. Potential for Land Application of 
Contaminated Sewage Sludge Treated with Fermented Liquid From Pineapple Wastes. Journal of Hazardous Materials 167: 866872.

Dey. A., Nath. S. dan Chaudhuri. S. 2012. Impact of Monoculture (Rubber and Pineapple) Practices on the Community Characteristics of Earthworms in West Tripura (India). Journal NeBIO 3 (1): 5358.

Elfiati. D., Delvian dan Hanum. H. 2016. Indeks Pelarutan Fungi Pelarut Fosfat dengan Menggunakan Empat Sumber Fosfat (Dissolving Index of Phosphate Solubilizing Fungi Using Four Phosphate Sources). Prosiding Seminar Nasional Lahan Suboptimal 201-214

Ginting, R.C.B., Saraswati, R. dan Husen, E. 2006. Mikroorganisme pelarut P. Dalam: Simanungkalit, R.D.M., Suriadikarta, D.A., Saraswati, R., Setyorini, D. dan Hartatik, W. (Eds.) Pupuk Organik dan Pupuk Hayati. Bogor: Balai Besar Litbang Sumberdaya Lahan Pertanian Halaman: 141-158.

Khan, M.S., Zaidi, A. dan Ahmad, E. 2014. Mechanism of Phosphate Solubilization and Physiological Functions of PhosphateSolubilizing Microorganisms. Edisi Phosphate Solubilizing Microorganisms. Springer International Publishing Switzerland. Department of Agricultural Microbiology, Faculty of Agricultural Sciences, Aligarh Muslim University, India. Halaman: 31-62

Kumar, D. Jain, V.K, Shanker, G dan Srivastava. 2003. Utilisation of Fruits Waste for Citric Acid Production by Solid State Fermentation. Journal Process Biochemistry 38 : 17251729.

Obiamaka, O.C. 2011. Effects of Household Compost on the Chemical Properties of Typic Paleudult in Nigeria. Malaysian Journal of Soil Science 5:35-48.

Ogbomo, L. dan Osaigbovo, A.U. 2017. Influence of Plant population and Cattle Manure
Application on Productivity and Profitability of Early Maturing Maize (Zea Mays L.) in Humid Ultisol. Journal of Organic Agriculture and Environment 5(1): 15-22.

Prasetyo dan Suriadikarta. 2006. Karakteristik, Potensi dan Teknoligu Pengelolaan Tanah Ultisol untuk Pengembangan Pertanian Lahan Kering di Indosenis, Jurnal Litbang Pertanian 25 (2): 39-47.

Purwaningsih. S. 2003. Isolasi, Populasi dan karakterisasi Bakteri Pelarut Fosfat pada Tanah dari Taman Nasional Bogani Nani Wartabone, Sulawesi Utara. Jurnal Mikrobiologi. Puslit Biologi-LIPI. 3(1): 4553.

Rahayu, Sumani, Suprayadi dan Umami, N. 2012. Pengaruh Pemberian Biomassa Thithonia diversifolia dan Bakteri Asam Laktat Terhadap Pertumbuhan Jagung, Ketersediaan Fosfor dan Alumunium pada Tanah Ultisol. Jurnal Caraka Tani 27 (2): 105-114.

Ramadhani, W.S. and Nuraini,Y. 2018. The Use of Pineapple Liquid Waste and Cow Dung Compost to Improve Availability of Soil N, $\mathrm{P}$, and $\mathrm{K}$ and Growth of Pineapple Plant in an Ultisol of Central Lampung. Journal Degrade. Min. Land Manage, 6(1): 14571465

Sanni, K.O. 2016. Effect of Compost, Cow Dung and NPK 15-15-15 Fertilizer on Growth and Yiesld Performance of Amarant (Amaranthus hybridus). Internatiomal Journal of Advances in Scientific Research 2(3): 76-82.

Tamad dan Maryanto. J. 2010. Media Pembawa Alternatif Inokulan Mikroba Pelarut Fosfat Berbasis Limbah Pertanian. Jurnal Agrin. 14(2): 167-176.

Tando. E., Nugroho. A dan Islami. T. 2017. Research Article: Effect of Sago Waste, manure and Straw Biochar on Peanut (Arachis hypogaea $\mathrm{L}$ ) growth and yield on an Ultisol of Southeast Sulawesi. Journal of Degraded and Mining Lands Management 4(2): 749-757. 
Zakaria, Z. A., Zakaria, Z., Surif, S., dan Ahmad, W. A. 2007. Biological Detoxification of Cr (VI) using Wood-Hush Immobilized
Acinetobacter haemolyticus. Science Direct Journal of Hazardous Materials 148 : 164171 